\title{
“ЯКАСЬ МОЗАЇКА СТРОКАТА І ВІРШІ РІЗНИХ РОЗМІРІВ": ПОПІЛ ІМПЕРІЙ ЮРІЯ КЛЕНА
}

\author{
POMAH MHIX \\ Природничо-гуманітарний університет, Сєдльце - Польща \\ mnichrw@yahoo.de \\ "JAKAŚ PSTRA MOZAIKA I WIERSZE RÓŻNYCH ROZMIARÓW": \\ POPIÓE IMPERIÓW JURIJA KLENA \\ ROMAN MNICH \\ Uniwersytet Przyrodniczo-Humanistyczny, Siedlce — Polska
}

STRESZCZENIE. Artykuł poświęcony został twórczości jednego z najwybitniejszych ukraińskich poetów XX wieku, przedstawiciela "neoklasyków", Jurija Klena (1891-1947). Przesłanie ideowe poematu Popiót imperiów zinterpretowano w świetle całej twórczości neoklasyka, również jego spuścizny naukowej. Szczególną uwagę zwrócono na fragment wskazanego poematu pt. Pokusa Lucyfera oraz przewodni dla niego obraz nadczłowieka (Übermensch).

\author{
"YAKAS MOZAIKA STROKATA I VIRSHI RIZNYKH ROZMIRIV": \\ THE ASHES OF THE EMPIRES BY YURI KLEN \\ ROMAN MNICH \\ University of Natural Sciences and the Humanities, Siedlce - Poland
}

ABSTRACT. The article focuses on the creative writing of Yuri Klen (1891-1947), the neoclassic and one of the most prominent Ukrainian poets in the twentieth century. The author interprets the main motifs of the poem Popil Imperij (The Ashes of the Empires) in the context of Klen's creative and academic writing. Special attention is paid to the analysis of a fragment known as Lucifer's Temptation, the key image of which is the image of the Übermensch.

\begin{abstract}
„Тепер мені просто насувається інтерпретація тодішніх настроїв Бурггарда його значно пізнішими словами: перед його очима розсипалися попелом імперії”. Дмитро Чижевський,

Юрій Клен, вчений та людина
\end{abstract}

$\mathrm{T}$ ворчість Юрія Клена (1891-1947) в українському літературознавстві вивчали побіжно, чи то разом з іншими неокласиками, чи то в контексті європеїзації української літератури, чи то в контексті тем та мотивів самого поета. При цьому бралися до уваги, як правило, лише ті тексти поета, які він друкував українською мовою після свого переїзду до Німеччини ${ }^{1}$ На жаль, до сьогодні немає серйозного дослідження ні про першу літературознавчу розвідку Освальда Бурггардта Новые горизонты в области исследования поэ-

\footnotetext{
${ }^{1}$ Шкода, що й до сьогодні в Україні не перекладена книжка Жозефіни Бурггардт Освальд Бурггардт. Життя і творчість (Josefine Burghardt, Oswald Burghardt. Leben und Werke. Biographie Jurij Klen's, München 1962, 112 s.). Попри недосконалість цієї розвідки — це єдине монографічне дослідження про життя та творчість Юрія Клена.
} 
тического стиля (приниипы Е. Ельстера), надруковану в Києві 1915 року, ні про його німецькомовні публікації в часописі "Zeitschrift für slavische Philologie"2, ні, зрештою, про його також німецькомовну дисертацію Die Leitmotive bei Leonid Andrejev ${ }^{3}$. А якщо вже говорити про поему Попіл імперій, то, напевно, над дослідниками й до сьогодні тяжіють сказані Євгеном Маланюком у передмові до другого тому канадського видання творів Юрія Клена слова: „Про повну оцінку такого твору, як Попіл імперій, говорити ще дуже завчасно. Такого роду твори вимагають передовсім певної «дистанції», перспективи"4.

Якщо задатися питанням, чому саме Попіл імперій є таким складним поетичним твором, то навряд чи можна знайти однозначну відповідь. Проте безперечними при відповіді будуть такі фактори, як незавершеність самого тексту, складність ліричного сюжету, що майже межує зі своєрідною еклектикою, насиченість асоціаціями як історичними, так і культурними тощо. Усі дослідники Попелу імперій одностайно погоджувалися в тому, що твір цей засадничо базується на інтертекстуальних зв'язках як з українською, так і зі світовою культурою та історією. Почасти ці зв'язки вже досліджували та інтерпретували, указувалося на ідейні та символічні функції так званих традиційних мотивів та сюжетів у поемі, художнє значення окремих образів та постатей. Проте загального тлумачення принципів звернення Юрія Клена до європейської спадщини, принципів відбору образів чи символів для реінтерпретації не маємо до сьогодні. Очевидно, проблемним $€$ саме питання про те, чи такий принцип існує, і чи Юрій Клен не відрізняється якоюсь абсолютно ще не дослідженою стороною творчості від інших українських неокласиків.

Зазначимо 3 цього приводу, що вже навіть пізніші сучасники поета, дослідники творчості “п'ятірного грона", писали про Ю. Клена як про поета особливого, чия творчість не зовсім вписується в загальний контекст так званого українського неокласицизму, хоч при цьому підкреслювали, що Караве$л и, „ є$ найкращим томом поезії, що їх нам доводилося читати з літературних новин за останні роки, а питання «поборення неокласики», про що говорить Маланюк, не таке то й просте"s. Дмитро Чижевський (дослідник творчості та давній друг поета) також згадує про Юрія Клена як про людину “незвичайну”, що ніколи „не давала вільного виходу своїм «незрілим» або «недозрілим» думкам та почуттям"6.

Можемо, напевно, зумисне підкреслити, що у випадку Юрія Клена маємо справу зі своєрідним українством - палким та до болю екзистенціальним, особливо тоді, коли поет залишив Україну. Це українство етнічного німця, що свідомо признавався до українства, і навіть більше - активно спричинився до розвитку української літератури та культури загалом. Українство Юрія Клена по-особливому акумулювалося після його остаточного від’їзду до

2 Укажу на найважливіші: 1) Die Entstehungsgeschichte eines Gedichtes von Vincenty Pol, [in:] „Zeitschrift für slavische Philologie”, 1937, Bd. XIV, s. 322-325; 2) Fremde Dichter im ukrainischen Gewande, [in:] „Zeitschrift für slavische Philologie”, 1938, Bd. XV, s. 260-302; 1941, Bd. XVII, s. 1-31; 3) Gemeinsame Motive bei Leonid Andrejev und Nietzsche, [in:] „Zeitschrift für slavische Philologie”, 1941, Bd. XVII, s. 353-372; 1942, Bd. XVIII, s. 1-18.

O. Burghardt, Die Leitmotive bei Leonid Andrejev. Kommissionsverlag Otto Harrassowitz, Leipzig 1941.

${ }^{4}$ Див.: Ю. Клен, Твори, за ред. Свгена Маланюка, Торонто 1957, т. 2, с. 9.

${ }_{5}^{5}$ В ол. Кри мс ьк и й, П'ятірне гроно (Українська неоклясика 20-тих років), [в:] „Студентський прапор", Краків 1944, число 4-5 (10-11), квітень-травень, с. 14.

${ }^{6}$ Див.: Д. Ч и же в с ьк и й, Юрій Клен, вчений та людина, [в:] Збірник „Української літературної газети" 1956, Мюнхен 1957, с. 157-166. 
Німеччини. На цей момент звертало увагу багато дослідників, і він безпосередньо відобразився в ідейному світі віршів Юрія Клена, написаних після виїзду до Німеччини, тобто після 1931 року. Таке особливе ставлення до України маємо в знаменитих рядках: Простягся шлях мені без перепон. / I, як вигнанещь-Данте, я покинув, / вітавши общир невідомих лон, / в ту ніч мою Флоренцію-Вкраїну.

Звичайно, сказати про Україну “моя Флоренція", а згодом у поемі Попіл iмnерій, написати „Священний граде мій, о Києве!”- означало екзистенціально признатися до українського народу та його культури. I напевно, зовсім не випадково у творчості Юрія Клена мотив туги є тим художнім мотивом, що визначає суть його світобачення як поета: „Dasjenige Motiv, das in die tiefsten Wesensschichten Klenscher Dichtungsart vordringt, ist das Motiv der Sehnsucht"8. Неоромантична туга викристалізовувалась у поезії Юрія Клена в концепцію туги за втраченими “скарбами мудрості”, утраченою доблестю з присмаком туги за батьківщиною.

Повертаючись до поеми Попіл імперій, згадаємо, як вже сам поет писав, що текст цього твору заволодів ним мимо його власної волі: „Я спочатку ставив собі скромне завдання - дати поему на кілька сот рядків, але вона, мимо моєї волі, росла, захоплюючи все ширші обрії, і мені довелось іiі розмір рахувати вже не сотнями, а тисячами рядків" ють спогади Анни Ахматової про те, як вона писала Поему без героя - твір, що теж ріс, “розбухав”, за словами поетеси, апелюючи кожен раз до нових аспектів європейської культури та історії ${ }^{10}$. Отже, маємо справу із ситуацією, коли задум не вкладається в реалізацію, творча реалізація ідеї перевищує можливу художню форму. В історії європейської літератури ця ситуація досить відома: вона наступила на поч. XIX ст. з приходом романтизму й занепадом риторичної епохи. Саме $з$ того часу літературні жанри перестали визначатися риторичною традицією, а почали набувати індивідуально-авторських рис. Автор вже не здатен був укладати новий зміст у традиційні жанрові форми, і зрозуміло, що найбільш послідовно ця авторська тенденція утверджувала себе в ліриці. У XX ст. ця тенденція посилювалась, що й відобразилось на різноманітній практиці літературних жанрів, добрим прикладом чого і є поема Попіл імперій.

Структурно поема має п'ять частин, кожній з яких притаманна певна цілісність, хоча б на рівні формальної єдності. Перша частина твору передає події від Першої світової війни до революції 1917 року. Але ця частина починається урочистими віршами вступу, що змістовно нагадують початок $\Phi a$ уста Гете. Ось рядки з першого вірша Попелу імперій Юрія Клена: У вічності, де світла струм тече, / повільно крутяться колеса часу, / що на верстаті золотому тче / свій килим різнобарвний. Дольні паси / пускає в рух незримий нам двигун ${ }^{11}$.

Пригадаємо початок Фауста Гете, а саме слова архангела Рафаїла із Прологу на небі: Die Sonne tönt nach alter Weise / In Brudersphären Wettgesang, / Und ihre vorgeschriebne Reise / Vollendet sie mit Donnergang ${ }^{12}$.

7 Докл. див.: О. Фили пов ич, Життя і творчість Юрія Клена, [в:] „Сучасність”, жовт. 1967, № 10 (82), c. 54.

${ }^{8}$ K. Siehs, Das Sehnsuchtsmotiv bei Jurij Klen, [w:] „Ammann — Festgabe”, Gruppe Slawistik. Innsbrucker Beiträge zur Kulturwissenschaft, Innsbruck 1954, Band 2, Heft 5 (10), s. 233.

${ }^{9}$ Ю. Клен, зазнач. джерело, с. 333.

${ }^{10}$ Див.: „Проза про поему” [в:] Анна Ахматова, Собр. соч., в 6-ти томах, том 3: Поэмы. Pro doто теа. Театр, Москва 1998, с. 213-278.

${ }^{11}$ Усі цитати з поеми Попіл імперій подаю за згаданим вище 2 томом Торонтського видання творів Юрія Клена.

${ }^{12}$ Goethes Werke in zwölf Bänden, Vi erter B and, Berlin-Weimar 1981, s.164. 
Не кажучи вже про значущість самої постаті архангела Рафаїла для Юрія Клена (нагадаю, що поет написав новелу Пригоди Архангела Рафаїла ${ }^{13}$ ), наведені вірші дуже подібні настроєм, спробою універсального погляду на події, конкретну історію через призму історії всесвіту ${ }^{14}$. Уже у вступних віршах до поеми маємо заданий загальний ритм твору, суголосний Гераклітовим сло-

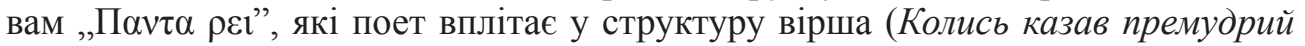

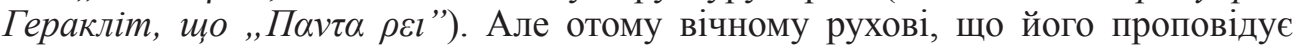
найтемніший античний філософ, протистоїть пам'ять. У концепції Юрія Клена категорія пам'яті має два виміри: універсальний, людський та історичний. Перший - універсальний - належить до Божественного провидіння, невидимої руки, що все оцінює й записує: Все віддзеркалить вічності екран. / Не пропаде тут жаден звук і порух, / і наму радість, біль і мрій дурман / чиєсь перо записує узорях.

Суголосно й паралельно цьому “перу в зорях" працює перо самого поета — це і є другий вимір пам'яті: він належить поетові. Поет фіксує й оцінює історію та події, його перо для людей є не менш важливим, ніж перо Господа. Поет зберігає для нащадків пам'ять про болі та страждання народу.

Ця перша частина поеми Юрія Клена закінчується досить показовим зверненням до читача - Розмова з читачем, де й подано взяті в заголовок цієї розвідки слова про “строкату мозаїку і вірші різних розмірів". Поет наголошує, що замість очікуваної поеми, читач отримав “стаккато” i “образів різноманітний рій”. Як бачимо, Юрій Клен як поет та теоретик поезії розумів, що його поема в жанровому плані не вписується в межі існуючої традиції.

Друга частина твору, як писав сам поет, “малює пекло, через яке довелося проходити нашому народові". У супроводі Данте поет проходить пеклом таборів примусової праці Радянського Союзу. Текст цього розділу поеми складається 3 трьох частин. Перша частина - Ad astra - це своєрідний короткий вступ, натомість дві наступні, що написані терцинами, не мають заголовку і є розповіддю про радянське пекло. Напевно, саме другий розділ поеми найбільш довершений та цілісний у художньому плані як формально, так і змістовно.

Частина третя Попелу імперій присвячена Європі та Німеччині: тут ідеться про час приходу до влади Гітлера, події Другої світової війни, трагедію німців під Сталінградом та роздуми про долю Європи. Текст об'єднує різноманітні часово-просторові координати: від Мюнхена і ланів Поділля до згадок про Адама та Єву, Суворова, Кутузова, Леніна, від історії великого цадика до історії Геббельса. Так само складною є і четверта частина поеми, що зображує події після закінчення війни. Тут простежуємо роздуми над долею Маніфесту комуністичної партії Карла Маркса, містерію з Фаустом, який поєднає як героя Гете, так і персонажа Томаса Манна, міркування про “двох сестер” - Україну і Росію тощо. Однак у центрі зображення доля Третього рейху Німецької держави: Дванадиять літ - і вже настав кінець / тисячолітньої держави. / I расова теорія, вінещь / наук, впадає у неславу.

\footnotetext{
${ }^{13}$ Див.: Р. Мн іх, Новела Юрія Клена „Пригоди Архангела Рафаӥла”: декілька штрихів до інтерпретації твору, [в:] Творчість Юрія Клена в контексті українського неокласииизму та вісниківського неоромантизму, Дрогобич 2004, с. 117-123.

${ }^{14}$ Спеціально про впливи Гете на творчість Юрія Клена див. статтю I. Качуров ського Відгуки творчості Гете в поезї Юрія Клена у його книзі Променисті сильветки. Лекиії, доповіді, cтатmi, есеї, розвідки (Мюнхен 2002, с. 294-311). Там само й розвідка I. Качуровського Життя і творчість Юрія Клена (с. 252-293).
} 
“Якась мозаїка строката і вірші різних розмірів": Попіл імперій Юрія Клена

Досить своєрідно в цей контекст уписується українська історія, культура та наука. Від згадки про конкретні події з історії України, конкретні постаті до натяків та асоціацій, пов'язаних із магістральними лініями розвитку української літератури. Згадаємо хоча б два показові приклади. Фінальні слова 3 вірша Червоний привид по таборах розповідають про розмову майора 3 ліричним героєм поеми, своєрідну дискусію про суть історії - української історії зокрема. Майор сідає в лімузин, а сам вірш закінчується так: Та мотором лють загуркотала. / Рушив він - $i$ з пліч гора, / $і$ ще довго, ніби дзвін метала, / вслід лунало: "Не пора!"

Останні слова - це відомий лозунг Івана Франка з його поезії Не пора!: Не пора, не пора, не пора / Москалеві й ляхові служить! / Довершилась України кривда стара, — / Нам пора для Украӥни жить.

Якщо брати до уваги, що розмова в поемі Юрія Клена відбувається в післявоєнний час у таборах полонених, де комісари агітують ліричного героя повертатися додому, на радянську Україну, то зрозумілим стає лозунг поета — настав час жити для України тут, у Європі, бо в радянській Україні панує такий самий режим, що панував у тоталітарній Німеччині.

До творчості Івана Франка звертається поет асоціативно й у вірші Вальпургісва ніч. Це найскладніша у філософському плані частина поеми, що загалом презентує роздуми про уклад усесвіту, віковічну боротьбу добра і зла та участь людини в цій боротьбі. Серед персонажів Вальпургієвої ночі зустрічаємо самого Бога, “старого романтика”, як його називає Люцифер, Фауста, Сатанаїла, згаданого Люцифера, відьму, хор матерів та хор дітей тощо. У плані художнього діалогу Юрія Клена з Іваном Франком цікавою видається промова Сатанаїла: Створив Господь світи. Чіткі орбіти / накреслив він планетам та сониям. / Він виростив кущі й духмяні квіти / і овоч дав він деревам. / Але на золотій, розлогій ниві, / скрізь, де шумить колоссям простір піль, / я, насадивщи будяка й кропиви, / посіяв руту і кукіль.

Наведені тут слова Сатанаїла повторюються і в новелі Юрія Клена Пригоди Архангела Рафаїла. Але і в поемі Попіл імперій, і в новелі Пригоди Архангела Рафаїла мотив злого демона, який сіє кукіль, щоб заглушити посіяне Богом (або добрим ангелом) зерно, є парадигматичним повторенням ситуації, зображеної в новелі Івана Франка Як Юра Шикманюк брів Черемош. Нагадаю для порівняння текст новели Юрія Клена: Запеклою була боротьба з Вертопрахом, що уночі приходив домагатися свойх прав і сіяв кукіль, який сходив там, де старанно вирошував золоту пшенищю Рафаїл, та глушив $\dddot{i ̆}^{\prime 15}$. Наведені слова 3 новели Юрія Клена й цитовані вище строфи Попелу імперій явно перегукуються з фіналом твору Івана Франка, що презентує розмову двох ангелів (власне кажучи, ангела й сатани): Ч о р н и й. Еге ж, еге! Вийшов сівач на поле сіяти, та й сіяв, кидаючи насліпо одно зерно на стежкк, друге в терня, третє в буйну пирійку, в надії, що хоч якась частина зійде, i виросте, й достигне, i дасть стосотні плоди. А собі сію свій кукілецьь розумно, з гарним обрахуванням. Де не можу зовсім заглушити твоєї пшенички, там хоч запоганю ї̈. Б і л и й. Що ж, роби, як знаєш і як мусиш! Поборемось ${ }^{16}$.

Зауважимо, що традицію Івана Франка Юрій Клен продовжував не тільки тематично (тема ангелів), але й формальними аспектами організації художнього тексту: і в І. Франка, і в Юрія Клена розмова ангелів оформлена драматичним

\footnotetext{
${ }^{15}$ Ю. Клен, Твори, за ред. С. Маланюка, Торонто 1960, том 3, с. 75.

${ }^{16}$ I. Франко, Зібр. творів, у 50-ти томах, Київ 1979, том 21, с. 472.
} 
діалогом, що так урізноманітнює прозовий дискурс новели Пригоди Архангела Рафаїла і віршовий дискурс поеми Попіл імперій.

Такою самою цікавою грою слів позначений початок вірша Bальпургієва ніч $з$ четвертої частини поеми Юрія Клена. Віршу передує епіграф з поезії Лесі Українки Мердвен (цикл Кримські спогади). Але найцікавіші початкові слова вірша Юрія Клена Досвітня мла в проваллях вирувала, бо вони прямо натякають на поезію Лесі Українки Досвітні огні. Як бачимо, наведені тут приклади свідчать про надзвичайну семантичну та символічну складність тексту поеми Попіл імперій.

Останню частину твору Юрія Клена — п'яту — складає Діалог людини з землею. Тут поет повертається до тієї універсальної проблематики, із якої поема починалась: до космічних вимірів історії. Розмова між людиною та землею точиться з позиції післявоєнних років XX століття. Людина втрачає віру в мудрість книжок, сенс власної історії ("не знає вже ні козака, ні князя син здичавілий темної орди”). Залишається тільки віра в працю, що може змінити сенс буття, і до такої праці закликає земля: “Потом гарячим мене напоі”. Це кінець тексту поеми Юрія Клена і кінець його роздумів про суть нашого буття.

Узагальнюючи наведені спостереження, можемо стверджувати, що два аспекти є першорядними, коли йдеться про розуміння та інтерпретацію поеми Попіл імперій: з одного боку, це проблема ідейно-естетичної, художньої єдності твору, з другого боку, - багатство змісту, асоціацій, інтерпретаційні можливості тексту поеми. Щодо першого аспекту, то мусимо зазначити передусім власне своєрідну “проблематичність” ідейної та художньої єдності твору: і формально, і змістовно, як свідчить прочитання тексту, поема Попіл імперій не є довершеним твором. Можливо, через те, що сам автор не встиг його довершити, а можливо, власне таким був задум Юрія Клена. Адже в минулому XX ст. жанр поеми в європейській літературі модифікувався настільки, що важко знайти його спільні естетичні чи ідейні критерії. Проте в поемі Попіл імперій ситуація ускладнюється тим, що сам текст написаний надзвичайно строкато, різними строфами, різними віршовими розмірами, з орієнтацією на різноманітні традиції: від античної трагедії з ії обов'язковими діалогами до Данте, Гете, Рільке і Стефана Георге.

Коли замислитися над питанням, що єднає таку “строкату мозаїку”, то поза образом ліричного героя навряд чи знайдемо ще щось спільне для всіх п'яти частин твору. У творі Юрія Клена немає ні єдиного ліричного сюжету (хоча $є$ формально хронологічна рама 1914-1945), ні певної єдиної системи персонажів, ні єдиного хронотопу. Звичайно, можна констатувати, що художня цілісність твору визначається передусім заголовком (Попіл імперій), семантика якого вбирає все $\mathrm{i}$, кажучи цитатою, зберігає все conservat omnia. Але ж відкритим залишається питання про те, який фенікс воскресне із зображеного поетом попелу імперій, тим паче, що радянська імперія після 1945 року аж ніяк не спопеліла. На це питання поема Юрія Клена відповіді не дає, хоч пропонує різні містичні візії та що є найважливішим - закликає до праці.

Із заголовком твору Юрія Клена пов'язаний задум - наступний аспект, що об'єднує всі частини поеми в єдине ціле. Авторська позиція й авторська візія історії проходять через увесь твір певним ідейним стрижнем: перед нами бачене та оцінюване однією людиною. Проблема та парадокс полягають власне в тому, що задум твору і відповідний йому заголовок, як на позір, лише формаль- 
“Якась мозаїка строката і віриі різних розмірів":

Попіл імперій Юрія Клена

но об’єднують ті вірші та уривки, що складають поему. I тому взаємозв'язки між частинами поеми набагато складніші, ніж це видається на перший погляд.

Досить яскравим доказом цього може бути вірш 3 третьої частини поеми Там, де над Зальцббергом синів простір, до інтерпретації якого звернемося наприкінці. Спробуємо приглянутися до цього цікавого тексту уважніше. Перше, на що треба звернути увагу, це те, що існує два різні варіанти публікації самого тексту. За життя поета цей уривок було надруковано в часописі „Літаври”, головним редактором якого був сам Юрій Клен. Уривок мав заголовок Люичферова спокуса (з поеми “Попіл імперій”, частина III)17. При передруку твору в складі поеми Попіл імперій у другому томі творів Юрія Клена цей заголовок опущено. Ще одна відмінність полягала в тому, що журнальний варіант тексту мав поділ на чотиривіршеві строфи, а в складі поеми текст надруковано суцільно.

Згаданий уривок цікавий тим, що розповідає про Адольфа Гітлера, а в центрі ліричного сюжету сцена спокуси Гітлера Люцифером (звідси назва журнального варіанта тексту). Така, по суті, ретроспективна фантасмагорична візія представляє осмислення як суті гітлеризму, так і загадки постаті самого Гітлера в німецькій історії ${ }^{18}$. Гітлер у Зальцберзі на терасі свого дому оглядає в романтичній задумі далечінь, а йому зі скелі Вацмана являється Люцифер і пропонує спокуси: Там, де над Зальичергом синів простір, / стояв він на терасі свого дому / i слухав, як мечі у надрах гір / йому послужливі кували гноми. / Там, над проваллів без глибом стрімким, / вилискуючи проти сонця й білі / від снігу, щзо здавався голубим, / ясні шпилі навколо височіли. / Ще ранкова від гір лягала тінь / на кам'янисті схили і долини, / і хтось, плащем розсікши далечінь, / зі скелі Вацммана до нього злинув / і станув поруч. А тоді почав / зорити разом з ним иирокий безмір.

Люцифер проповідує всі майбутні теорії фашизму (безсмертний міт про найвищу расу, володарювання на землі, теорія надлюдей і т. д.). Найдивніше те, що парадигматично в ліричному сюжеті Юрія Клена Адольф Гітлер стоїть на місці Ісуса Христа: так, як колись Ісуса Христа спокушав Люцифер, так само тепер Люцифер спокушає Гітлера. Ця ситуація прямо нагадує відомий уривок з Свангелія від Матвія: „Darauf führte ihn der Teufel mit sich auf einen sehr hohen Berg und zeigte ihm alle Reiche der Welt und ihre Herrlichkeit und sprach zu ihm: Das alles will ich dir geben, wenn du niederfällst und mich anbetest" (Mth. 4,8).

Порівнюючи Гітлера 3 Христом, Люцифер промовляє: Tu, як Мойсей, створи безсмертний міт. / Чи ж нарід твій не є найвища раса? / Дається їй опанувати світ, / бо решта - то драглиста маса... / Надлюди ви, півбогивладарі, / шзо вимріяв їх смілий Заратустра... / Веди, немов Ісус - але Навин, / а не Христос - ті раті до звитяги, / і до твоїх прихиляться колін / багнети, берла, голови і стяги... / Міси, як майстер глину, людську твань.

Проте вся ця фантасмагорія зникає, як мильна бульбашка: I світ звичайним став на ока кид: / десь череду ганяли волопаси, / знов обступили гори краєвид / і в нім самотню постать на терасі.

Образ романтичної “самотньої постаті на терасі” та ніцшеанський дискурс про надлюдей і Заратустру змушує задуматися над долею європейської історії в 30-ті роки минулого століття. Як етнічний німець Юрій Клен, очевидно,

17 Див.: Ю. Клен, Люциферова спокуса, [в:] „Літаври” 1947, число 3, червень, с. 3-5.

18 Серед чисельних спроб осмислення постаті Адольфа Гітлера в контексті подій 20 ст. й історії Німеччини назвемо найновішу наукову біографію: J о ach im Fest, Hitler. Eine Biographie, Spiegel-Verlag, Hamburg 2007. 
сприймав болюче події перед Другою світовою війною, а також не менш болюче осмислював фінал цієї війни. Серед різноманітних інтерпретацій щодо приходу до влади Гітлера в Німеччині не останньою $є$ й теорія про романтичну суть націонал-соціалізму ${ }^{19}$ i його оновлюючий потенціал для тодішньої Німеччини. Так само творчість і постать Фрідріха Ніцше на той час презентували шкалу нових цінностей, $\mathrm{i}$, очевидно, ніхто не задумувався над трагічною суттю розпочатих Гітлером перебудов: „Man sieht Nietzsche als den Schöpfer neuer Werte... Der Übermensch wird als Symbol für den freuen Geist und Schöpfer verstanden, Also sprach Zarathustra erinnere an Goethes Faust. Man betrachtet den Übermenschen als Verkünder einer neuen Kultur, die an die Stelle der Kultur des christlichen Abendlandes treten soll. In vielen Interpretationen erkennt man den Einfluß Darwins..." ${ }^{20}$. Отож націонал-соціалізм і ніцшеанський дискурс із музикою Вагнера дійсно творили в 30-ті роки не тільки в Німеччині, але й у Західній Європі загалом новий захоплюючий стиль життя, і ця тенденція знайшла відображення в тексті Юрія Клена.

Зауважимо також, що певна пересторога від захоплення Ніцше, а через нього й Вагнером з боку поетів була. Досить згадати вірш Павла Тичини Кукіль (Kornrade): Стріляють серие, стріляють душу - нічого їм / не жаль. /... Сіло собі край вікна. засунуло пучечку в рота, / маму визирає. А мати лежить посеред улииі / з півхунтом хліба у руиі... / Над двадиятим віком / кукіль $і$ Парсифаль ${ }^{21}$.

Як бачимо, П. Тичина прямо осмислює суть XX ст. через символ інспірованого Ніцше і Вагнером Парцифалю, але трагедія полягає в тому, що поряд і на рівні цього героїчного Парцифалю стоїть бур'ян кукіль - символ розладу і занепаду. Той самий кукіль, символ якого так міцно закоренився в українській художній традиції від Івана Франка до Юрія Клена. I цей кукіль спричиняється до того, що романтика виявляється гнилою і, очевидно, що саме така теорія відображена в цитованому уривку з поеми Юрія Клена Попіл імперій.

У цій науковій розвідці названо лише поодинокі семантичні аспекти, необхідні для розуміння та інтерпретації поеми Юрія Клена. Варто додати, що розгляд та інтерпретація твору Юрія Клена (Освальда Бургхарда) Попіл імперій може проводитися в двох аспектах: (1) жанрово-стильовому та (2) символічному. Перший можна назвати філологічним, він базується на розумінні закономірностей літературного розвитку, розумінні специфіки літературного твору. Суть такої інтерпретації полягає передусім у тлумаченні жанрово-стильових особливостей художнього тексту. І тут поема Юрія Клена презентує повне порушення законів жанру. Другий тип інтерпретації не прив'язаний ані до жодної традиції, ані до жодної методології: він базується на тлумаченні сенсу тексту в його семантикосимволічних вимірах та асоціативних рівнях. У цьому аспекті Попіл імперій ще тільки чекає на своїх дослідників, роботи в яких - непочатий край.

Юрій Клен написав твір герметичний, ніби реалізуючи думку Гегеля про те, що в справжнього поета і перед, і під час написання тексту творче, художнє натхнення поєднується з логічними та науковими роздумами і міркуваннями ${ }^{22}$.

${ }^{19}$ Порів.: "Nationalsozialismus ist politische Romantik, so also lautet eine Diagnose unmittelbar vor der Machtergreifung Hitlers, und es ließen sich noch viele andere kritische Stimmen aus den letzten Jahren der Weimarer Republik zitieren, welche auch in diesem Sinne geurteilt haben" (Rü drig er S a franski, Romantik. Eine deutsche Affäre, Carl Hansen Verlag, München 2007, s. 348 ). Див. розділ "Wie romantisch war der Nationalsozialismus" у цій книзі.

${ }^{20}$ Giorgio Penzo, Übermensch, [in:] Nietzsche-Handbuch. Leben - Werk - Wirkung, hrg. von Henning Ottmann, Stuttgart 2000, s. 344.

${ }^{21}$ П. Т ичин а, Сонячні кларнети, Київ 1990, с. 130.

22 Див. про це докладно в кн.: Філософї̈ Духа, [в:] Енциклопедія філософських наук, т. 3, кінець § 449. 